Al-Uqud: Journal of Islamic Economics E-ISSN 2548-3544, P-ISSN 2549-0850 Accredited No. 28/E/KPT/2019
Volume 4 Issue 2, July 2020

DOI:10.26740/al-uqud.v4n2.p174-185

Page 174-185

\title{
Corporate Social Responsibility in Morocco: Are Small and Medium-Sized Enterprises (SMEs) Socialy Responsible?
}

\begin{abstract}
Ait Mhamed Hind*
Centre for Doctoral Studies Law, Economics and Management, National Business and Management School-Tangier, University Abdelmalek Essaadi- Tetouan Principal Post of Tangier, BP1255, Morocco

Abstract: CSR's dynamism in Moroccan business is very recent. It was started in 2006 with the initiative of the Moroccan Confederation of business associations (CGEM) through the CSR label. Nowadays, more than 70 companies in the majority of large firms had been labelled. In the same year, the Moroccan Kingdom accedes to the Global Compact. At the policy level, the country has presented its achievements regarding the objectives millennia and began the implementation of the objectives of sustainable development. In this dynamism, what about SMEs? Which are the key importance of the Moroccan economy? Therefore, the study aims to explore the existence of a specific CSR in the Moroccan context by focusing on SMEs' social practices. This study uses a qualitative approach based on a case study method that aimed at a scoping study in Moroccan CSR's nature. Our analysis demonstrates that SMEs' social practices would be socially responsible ones' and would reflect an implicit CSR that explained by the motivations of these practices and the relationship of SMEs with its stakeholders.
\end{abstract}

Keywords: Corporate Social Responsibility (CSR); Moroccan; SMEs

Paper type: Research paper

*Corresponding author: aitmhamed.hind@ gmail.com

Received: January 09, 2020; Accepted: April 13, 2020; Available online: April 27, 2020; Published regularly: July 2020

Cite this document: Hind, A. M. (2020). Corporate Social Responsibility in Morocco: Are Small and Medium-Sized Enterprises (SMEs) Socialy Responsible? Al-Uqud: Journal of Islamic Economics, 4(2), 174-185. doi: http://dx.doi.org/10.26740/al-uqud.v4n2.p174-185

Copyright () 2020, Al-Uqud: Journal of Islamic Economics http://journal.unesa.ac.id/index.php/jie 
Abstrak: Dinamika CSR dalam bisnis Maroko sangat baru. Aktivitas ini telah dimulai pada tahun 2006 oleh inisiatif Konfederasi Asosiasi Bisnis Maroko (CGEM) melalui pemberian label CSR pada perusahaan dan produk. Saat ini, lebih dari 70 perusahaan di sebagian besar perusahaan besar telah diberi label sebagai perusahaan yang ber-CSR. Pada tahun yang sama, Kerajaan Maroko berkomitmen untuk menerapkan prinsip-prinsip Global Compact. Pada tingkat kebijakan, negara tersebut telah mempresentasikan tujuannya dan memulai implementasi tujuan pembangunan berkelanjutan. Dalam dinamika ini, bagaimana dengan peran UKM? Apa kunci utama perekonomian Maroko? Oleh karena itu, penelitian ini bertujuan untuk mengeksplorasi keberadaan CSR tertentu dalam konteks Maroko dengan berfokus pada praktik sosial UKM. Penelitian ini menggunakan pendekatan kualitatif berdasarkan metode studi kasus yang bertujuan untuk studi pelingkupan dalam sifat CSR Maroko. Analisis kami menunjukkan bahwa UKM telah menerapkan tanggung jawab sosial, meskipun beberapa masih bersifat CSR tersirat dimana dalam penelitian ini dijelaskan oleh motivasi usahawan UKM untuk menerapkan CSR dan bagaimana mereka menjaga hubungan UKM dengan para pemangku kepentingannya.

Kata kunci: Tanggung Jawab Sosial Perusahaan (CSR); Maroko; UKM

\section{INTRODUCTION}

The engagement reasons in CSR for small and medium-sized enterprises (SMEs) and Multinational Companies (MNC) are not always the same. SMEs generally do not have the same interest, the same means (financial and human) and the same media visibility as MNC to implement and publicize such an approach, even though they encounter a certain number of difficulties that MNC manage to circumvent more easily (Depret, Le Masne, \& Merlin-Brogniart, 2009).

SMEs connected to globalized industrial networks are in a situation where it is necessary to integrate CSR principles, but also to report on them credibly, at the risk of being sidelined in favour of partners less likely to put in danger the MNC's reputation. Romano, (1995) considers that SMEs would be increasingly dominated by the binding standards of Big companies and thus forced to adapt their management practices accordingly. This is a widespread case, which can be described as imposed CSR: it exists in Morocco in several sectors dedicated to exports. The primary motivation for this CSR is economical to keep the client.

Alongside these SMEs, others, a vast majority, remain relatively on the sidelines of the global industrial dynamic imposed by the large globalized companies, which allows them to preserve their identity as "classic" SMEs to borrow from the terminology of Torres (1999). Nevertheless, this does not necessarily mean that they do not aspire to or at least do not demonstrate, CSR-like practices (via the person of the owner-manager). It is this hypothesis that we support in this paper; that of the existence of implicit CSR (in the sense of Matten \& Moon, 2008; but also the sense of (Gond, Igalens, Swaen, \& El Akremi, 2011) that is motivated by considerations other than economic ones. In this sense, we proposed to focus our interest on SMEs (and VSEs) whose capital is entirely Moroccan and whose market is exclusively national, to understand some significant elements on their motivations for practising CSR. 
Therefore, we propose to restitute, in a first step, the latest findings around the CSR and HRM report before extending the dialectic of this relationship to the examination of the economic ideology based on a purely religious corpus in the owner-manager of the Moroccan SME. This corpus is part of the register of implicit CSR, which we will outline below and which we will explain further on thanks to our empirical observation.

CSR in Morocco seems to be closer to the implicit mode than the explicit mode, but not to the degree that is not quite comparable with Europe. On the one hand, as in many developing countries, social and environmental problems are not taken care of by the Moroccan state and society does not yet have a determining influence on the orientations and choices of companies from a CSR perspective. On the other hand, the sharp divide between large enterprises (GE) and small and medium-sized enterprises (SMEs), which account for more than 95\% of the country's productive fabric, suggests a differentiated interest in CSR, in terms of intensity, nature, and stakes.

Moreover, an examination of the dynamics of CSR in Morocco since the mid2000s shows that the overall context tends to be favourable - driven by favourable legal and institutional reforms (El Abboubi \& El Kandoussi, 2010), especially for GEs and some SMEs open to external markets.

Comparing SMEs between Morocco and Tunisia, Labaronne and GanaOueslati (2012) have shown that while the international arrangements are similar for both countries, Morocco has an institutional framework that is more focused on CSR while Tunisia's is more oriented towards SD. This expresses the national imprint, or contextualization, of these systems, which has already been highlighted in studies on other geographical areas (Capron \& Quairel-Lanoizelé, 2007).

Far from purely economic or ecological considerations, we favour the path of HR practices concerning CSR. The objective is to explore the social fibre of SME managers through various operational events within the company while paying attention to the motivations that drive them. From this angle, we will focus on the spiritual dimension understood as a set of individual practices of the religious text (Islam).

\section{RESEARCH METHODS}

To better understand this theme and given its emerging and contextual nature, we opted for a qualitative approach based on a multi-case study. We have carried out this work of understanding and identification through six case studies that allowed us to analyze the managerial practices and discourse of associate managers. Knowing the centrality of the owner-manager in the SME, as we have seen above, and knowing that he or she most often combines the HR function, the study set itself the objective of interviewing six owner-managers of SMEs of different sizes, from different sectors of activity, intending to satisfy the conditions of variety and differentiation recommended in the determination of the sample by Sanséau, (2005).

Also, to eliminate the bias of foreign influence (imposed CSR), the study focused on SMEs with strictly Moroccan capital and no link with the foreign market (thus no exports). First, the selected firms are SMEs, and the capital must be $100 \%$ 
Moroccan. Second, the Chief Executive Officer (CEO) is the only owner of the business, and The company is a no exporting one to remove pressure from foreign contractors (imposed CSR) (Meknassi, 2009). Finally, The company must comply with the labour law.

The following table presents our six cases:

Table 1. Cases' sectors

\begin{tabular}{lcc}
\hline \multicolumn{1}{c}{ Sector } & $\begin{array}{c}\text { Number of } \\
\text { cases }\end{array}$ & Managed by \\
\hline Textile & 2 & Men \\
Metallurgy & 1 & Women \\
Services & 1 & Men \\
Advertising industry & 2 & Men \\
\hline Total & \multicolumn{3}{c}{$\mathbf{6}$ cases } \\
\hline
\end{tabular}

Source: Author's conception

The data were collected through interviews, documentation, and observation.

\section{RESULTS AND DISCUSSION}

Table 2. Date of creation and staff

\begin{tabular}{lccc}
\hline & Date of Creation & Start-up Staff & $\begin{array}{c}\text { Current staffing } \\
(\mathbf{2 0 1 5})\end{array}$ \\
\hline Case 1 (Textile) & 2009 & 10 & 180 \\
Case 2 (Adv.ind) & 2006 & 2 & 18 \\
Case 3 (Adv.ind) & 2002 & 4 & 12 \\
Case 4 (Textile) & 2013 & 10 & 200 \\
Case 5 (Metallurgy) & 2007 & 2 & 50 \\
Case 6 (Service) & 2009 & 2 & 15 \\
\hline
\end{tabular}

The average seniority of our cases is six years and six months of presence in the national market. We find that some have been able to make remarkable progress in the development of their enterprises; this is explained by two main reasons: family support and the effect of experience in the field.

Table 3. CEO profile

\begin{tabular}{lcccc}
\hline & Gendre & Age & $\begin{array}{c}\text { Education } \\
\text { Degree }\end{array}$ & $\begin{array}{c}\text { Worker } \\
\text { Experience }\end{array}$ \\
\hline Case 1 (textile) & Man & 44 & Bac+2 & 10 years \\
Case 2 (metallurgy) & Women & 40 & Bac+4 & 5 years \\
Case 3 (Adv.ind) & Man & 31 & Bac+4 & No \\
Case 4 (textile) & Man & 38 & Bac+4 & 5 years \\
Case 5 (Adv.ind) & Man & 40 & Bac+4 & 5 years \\
Case 6 (service) & Man & 33 & Bac+4 & 4 years \\
\hline
\end{tabular}

The average age is 39.5 years, a young population with varying work experience. All leaders have undergone advanced training. 
Companies' practices are strongly anchored in the economic, social, legal, political and even ideological environment in which they find themselves. They can either influence or be influenced by their environment. According to our study, companies are not just looking for profitability, and they also assume some social responsibility towards the employees and even the community.

The social and relational link is critical in the company because this one is a means of prosperity through which the businessman assumes his responsibilities towards society. The creation of a business must enable the promoter to make a living from it and ensure a particular social consideration or ascent. The cases of our research reflect the values and principles of its owner. However, these practices are self-evident and are not translated into a code of conduct or a declaration of good practice, or merely a list of general rules specifying these values.

In this study, the vision of CSR seems to be faced with a dual influence. The Moroccan context is different from the European or American context. Approaches to CSR should be designed with this variable in mind. Several research and institutions agree on these differences (Golli \& Yahiaoui, 2009; Visser, 2006, 2009).

On the occasion of the convention of the African Institute for the Citizenship of Enterprises concluded in Johannesburg, it was found that there is a mismatch between the visions, the African foundations, and justifications for CSR on the one hand and the Western ones on the other. Therefore, seek the origin of [a company's] success, as P. Labazée asserts, not in the transmission of monetary capital, but a stock of knowledge and relationships essential to the realization of business fostering the accumulation of departure» (Wong \& Yameogo, 2011). Relational capital is a substitute for often inadequate personal savings. Thus, the desire to make a profit does not disturb the social, relational bond that is at the origin of economic activity. This is why the entrepreneur combines economic efficiency with social constraints.

Case 1: "For me, I am working towards a target of 1000 recruitments. For me, this is the most important profit"

Case 2: It is thanks to civil society that I was able to develop my business. The establishment of this training center is a duty and accountability to my country"

Case 3: The manager must not seek only profit. Sometimes it would be necessary to get involved in small projects with a small margin but a big "Baraka" for the company

Case 4: "I reserve 5\% of the turnover each year for charitable purposes" 
Within the framework of a CSR approach in Africa, the relational capital extended to the whole community is, according to U. K.-S. Yaméogo, the essential resource that the company must preserve: the social link here is the resource, and the preservation of this resource confers legitimacy on the entrepreneur.

\section{The Motivations Behind the Implementation of These Practices}

Case results enshrine the primacy of spiritual values and personal beliefs of the leader over the strategic determinants of practice implementation. The influence of the owner leader, as the main actor of the SME, has been demonstrated by SME specialists like Tores.

In this study, the practices discussed with leaders are an evident and moral duty to society.

Case 1: Me: the factory stop to perform in the prayer time, is not expensive for you?

D1: for me, I calculate it from another point of view, it is a beneficial break for my employees, they resume their work with a renewed dynamic, it is win-win time"

Case 2: I: Why do you invest in these practices when you do not have to?

D2: it is the least I can do as a business leader, it is thanks to civil society that I have succeeded; so it is a duty to my country and my way of contributing to its development"

The motivations of leaders reflect a desire-based emotional commitment, which refers to the leader's identity, relationships with the company and positioning.

The analysis of the interviews shows that law and ethics form the basis of the vision of SME leaders. Indeed, the six leaders share the view that compliance with the law is indispensable and indisputable.

D1: "the first thing to do is to ensure employees' rights."

D2: «in our trade, the experience is indispensable, we have recruited profiles with 20 years of experience, this cannot be achieved if we do not comply with the law. Besides, compliance with the law is a duty I cannot neglect. These are the rights of employees I cannot ignore them».

D3: "since the creation of the company I assure in-person compliance with the law and I do not imagine myself outside the law" 
D4: "our employees are, without exception, reported and paid above the SMIG"

D5: "absolutely, respect for the law is essential."

D6: «all our employees are paid above SMIG with the social cover. The last salary is at 3200dh net»

In terms of the relationship with the union, our cases share the non-existence of union representation since all fundamental rights are guaranteed. In asking the question on this aspect, the answer is "it is the employees who do not want union representation."

The implementation of these practices is influenced by managerial values (Hambrick \& Mason, 1984). At the literature level, different authors have studied the relationship between an individual's perception of ethics, CSR and his ethical ideology (Van Kenhove, Vermeir, \& Verniers, 2001; Vitell, Ramos, \& Nishihara, 2010). Indeed, an individual's managerial values are a component of his ideology, consisting of norms, beliefs, and values (Van Kenhove, Vermeir, \& Verniers, 2001).

The reference to the principles of Islam is present in the statements of the leaders. This is consistent with research by Wood, (1991), Branzei, Vertinsky, \& Zietsma, (2000), Reynaud, et al., (2008), which emphasizes the importance of the personal values of organizational action, as organizational action is not abstract, but it is the result of human actors (Branzei, Vertinsky, \& Zietsma, 2000; Wood, 1991; Reynaud, et al., 2008). Also, the ethical ideology of the entrepreneur in the Moroccan SME has a strong influence.

Exploring the religious dimension of this CSR was therefore not an objective in itself. This is very important for two essential reasons. On the one hand, it allows the results to be put into perspective in the sense that they are not exhaustive, and the subject of religion has not been explicitly addressed as a theme. On the other hand, the risk is minimized by being faced with respondents who develop a "conscious" discourse about religion in connection with work and business.

In what follows, it will be a question of declining in the most methodical way possible the various manifestations of the religious dimension in the management of SME managers; this study does not specify the name or identity of the owner. It should be noted that the interviews were conducted in both languages, Arabic and French, and especially that the passages where elements related to the religious are systematically in Arabic. Consequently, we opted for the presentation of verbatim texts in English (meaning translation) in the body of the text.

\section{External pressures}

Historical work shows that the idea of Social Responsibility is spreading in the Society and business circles since the end of the 19th century, in the context of the transformation of American capitalism (Epstein, 2018).

The radical increase in the size of American industrial enterprises and the progressive advent of "an era of organizers", concomitant with the renewal of the economic fabric of SMEs, marked a profound change in the company's status at the beginning of the 20th century (Acquier \& Gond, 2007). 
Thus, companies are confronted with new protest movements, which will give rise to a massive wave of regulation in the 1960s and the first half of the 1970s. Beyond the rise of consumer movements, the 1960s were marked by the emergence of concerns about equal rights and discrimination (Vogel, 1986).

These social movements are a key factor in the emergence and development of CSR. In this study, this dimension does not exist; leaders say they have good relations with neighbours and they have never received a claim.

D5: "Printing machines exist in the basement, we have the license to practice, and we have implemented a soundproofing system; so we have no problem with the neighbours.»

D6: Since our installation, we have never received a complaint from our neighbours, we are on the top floor and thanks to the soundproofing no sound, and you can see it now at the time of our discussion».

Another source of pressure is customers who require precise dimensions to be respected and even labels or certifications to establish a contract. As part of our research, the customers of these SMEs insist on price-quality; first, compliance with the law or the environment is not a point of divergence. Among the explanations received is that there is not a particular awareness in this sense or even a devaluation for the product:

D5: If you offer a customer a print with recycled paper, he takes it badly, a customer told me, 'I will not make the impression with paper rubbish.»

\section{How CSR Reflects Islamic Values?}

If Protestantism defines CSR basically on Principal Trusteeship and Stewardship, referring to the idea that ownership is only justified if it will serve the community and its welfare. In Islam, CSR could be based on two fundamental principles: Istikhlaf (the succession of Allah), Attaqwa (conscience in Allah).

\section{Istikhlaf and The Management of Property Rights}

This principle corresponds perfectly to the Protestant principles and defines the contours of property rights and their management in Islam. Believe in Allah and His Messenger, and spend what He has given you the Vicegerency. Those of you who believe and spend [for the cause of Allah] will have a great reward." (Qur'an 57:7). This verse clearly expresses that the human being does not possess money and that absolute property does not exist.

However, this does not prejudice individual freedom and responsibility but leads to a rather societal form of ownership which is likely to avoid certain abuses such as the concentration and/or accumulation of capital, waste of wealth, hoarding. Islam, through the concept of "Khilafah", provides for commercial enterprises as protectors, not only of the financial resources of shareholders, but also of the economic resources of society, holding their goods for the benefit of society as a 
whole and, ultimately, achieving God's blessing. This implies an unavoidable need for companies to instil good CSR practices in their business conduct, covering issues such as good environmental practice, safety at work, philanthropic contributions, including socially beneficial activities and initiatives.

\section{Attaqwa: The Sense of Responsibility and Conduct of Business}

This principle is fundamental in Islam. The word Attaqwa has been quoted 151 times in the Quran, it is defined as a state of mind connecting the human being with Allah, as the prophet explains: «Fear Allah, where you are» and «reverential fear, is here» (making a sign by pointing his index to his heart...). This notion is a source of equality, solidarity, and harmonization between well-being and spiritual values for the individual, leading him to seek acts to admire and approach Allah.

To do this, a set of elements must be taken into account to encourage these companies to integrate CSR explicitly, to take an interest in international standards and to integrate a strategic CSR into their organizations.

Therefore, a man is not expected to carry out his economic, social or any other activities, as an economic agent that maximizes egocentric utility, as idealized in the neoclassical economy; instead, it should strike a balance between the rights and responsibilities of the individual and society (Chapra, 1992). Thus, the notion of social responsibility finds its foundations in Islam.

It is clear that it is the Company (lever of wealth creation, and space for developing new social links) that offers the most fertile field for such a cultural change, and by way of consequence, resolution of the economic and social stakes hitherto considered solely within the jurisdiction of the State, hence the need to make room for the Ijtihad by distinguishing the principle of Faith and (democratic) principles the debate, through the promotion of its specificities as an ingredient of the universal (spiritual, artistic, social experiences); to reclaim "managerial" the accumulated history of Islam as a religion, "Muslim" societies in their differences and Arab-Muslim civilization in its contributions to science and the universal. Research on the Islamic vision focuses on the "Taqwa" (God's consciousness) paradigm for understanding Islam's position on CSR. In other words, the Taqwa paradigm inspires a company that operates in an ethical and socially responsible way.

Islam offers an integrated spiritual view based on the teachings of the Qur'an and the Sunnah, which constitute a philosophical framework defining man's interaction with those around him (Dusuki, 2008). The ethical principles presented in the Qur'an can be used as guidelines or code of ethics for companies in carrying out their activities as well as their social responsibilities. Islam requires man to submit to Sharia law and encourages him to respect the moral norms as well as the social norms founded by it.

\section{CONCLUSION}

The results of our research have contributed to the understanding of the current dynamics of CSR at the level of the Moroccan no exporting SME, but by exploiting them in social issues and how companies practice CSR are beyond the law on the 
one hand, but close to the motivations and spiritual expectations of collaborators on the other.

In this context, the analysis of the results made it possible to qualify two aspects of the CSR-HRM practices of the Moroccan SME. First, at the level of discourse, we see that it is symptomatic of a conviction based on religion, the values of the entrepreneur and their influence on the conduct of the enterprise. Second, managerial actions (CSR practices) are revealing of the religious dimension by corroborating both the discourses and expectations of employees. These practices do not need any institutionalization effort, as they are disseminated in the sacred rituals of the collaborators: prayer, almsgiving, youth, mutual aid, cooperation, empathy, and others.

The study highlights two main areas of CSR marked by interdependence and complementarily: economic and social. This is explained in part the centrality of the role of the leader who is more concerned with the balance of his internal system and the density of the most influential stakeholders within the legal and organizational envelope of his SME. His scope based on the attempt to link Human Resources (HR) practices with the spiritual inclinations, aspirations, and expectations of collaborators. His discourse and actions are fused and naturally in the specificity of his cultural and more precisely spiritual context.

This reading from the prism of HR and spirituality opens a path to deepen the aspirations and expectations of the collaborators and cross them with the perspective of the leader. We also believe it is important to revisit the issue of the sustainability of socially responsible investments and even link them with social entrepreneurship projects and initiatives related to what we have deduced from results (Sadaqa Jaria/ Sustainable Alms).

\section{REFERENCES}

Acquier, A. \& Gond, J. P. (2007). Aux sources de la responsabilité sociale de l'entreprise: À la (re) découverte d'un ouvrage fondateur, Social Responsibilities of the Businessman d'Howard Bowen. Finance contrôle stratégie, 10(2), 5-35.

Branzei, O., Vertinsky, I., \& Zietsma, C. (2000). From Green-Blindness to The Pursuit of Eco-Sustainability: An Empirical Investigation of Leader Cognitions and Corporate Environmental Strategy Choices. Academy of management $\quad$ proceedings, 2000, C1-C6. https://doi.org/10.5465/apbpp.2000.5535908

Capron, M. \& Quairel-Lanoizelé, F. (2007), La responsabilité sociale d'entreprise, collection Repères, La Découverte, Paris, 122 pages.

Chapra, M. U. (1992). Islam and the economic challenge. International Institute of Islamic Thought (IIIT).

Depret, M. H., Le Masne, P., \& Merlin-Brogniart, C. (2009). De la responsabilité sociale des acteurs. Marché et organisations, (1), 13-37. https://doi.org/10.3917/maorg.008.0013

Dusuki, A. W. (2008). What does Islam say about corporate social responsibility? Review of Islamic Economics, 12(1), 5-28. 
El Abboubi, M., \& El Kandoussi, F. (2010). Le virage de la responsabilité sociale au Maroc. Le cas du secteur agroalimentaire. Reflets et Perspectives de la vie économique, 48(4), 69-77. https://doi.org/10.3917/rpve.484.0069

Epstein, M. J. (2018). Making sustainability work: Best practices in managing and measuring corporate social, environmental and economic impacts. Routledge.

Golli, A., \& Yahiaoui, D. (2009). Responsabilité sociale des entreprises : Analyse du modèle de Carroll (1991) et application au cas tunisien. Management \& Avenir, $n^{\circ}$ 23(3), 139-152. https://doi.org/10.3917/mav.023.0139

Gond, J. P., Igalens, J., Swaen, V., \& El Akremi, A. (2011). The human resources contribution to responsible leadership: An exploration of the CSR-HR interface. Journal of business ethics, 98(1), 115-132. https://doi.org/10.1007/978-94-007-3995-6_10

Hambrick, D. C., \& Mason, P. A. (1984). Upper echelons : The organization as a reflection of its top managers. Academy of management review, 9(2), 193206. https://doi.org/10.2307/258434

Matten, D., \& Moon, J. (2008). "Implicit" and "explicit" CSR: a conceptual framework for a comparative understanding of corporate social responsibility. Academy of management Review, 33(2), 404-424. https://doi.org/10.5465/amr.2008.31193458

Meknassi, R. F. (2009). Quel avenir pour la responsabilité sociale des entreprises au Maroc? In Droits de l'Homme et développement durable: Quelle articulation? (L'Harmattan, p. 173-192).

Meknassi, R. F. (2011). Chapitre XIII: la réceptivité des entreprises à la RSEQuelques considérations à la lumière de l'expérience marocaine. In Responsabilité sociale de l'entreprise transnationale et globalisation de l'économie. Bruxelles: Emile Bruylant

Reynaud, E., \& et. al. (2008). La responsabilité sociale de l'entreprise à l'épreuve de l'Europe. Revue française de gestion, 180, 109-130. https://doi.org/10.3166/rfg.180.109-130

Romano, J. (1995). La modernisation des PME: l'expert, le patron et le politique. Presses universitaires de France. In Lapointe, A. (2006). O economia Human. Bulletin Oeconomia Humana, 4(11), 4-7.

Sanséau, P.Y. (2005). Les récits de vie comme stratégie d'accès au réel en sciences de gestion: pertinence, positionnement et perspectives d'analyse. Recherches qualitatives, 25(2), 33-57.

Van Kenhove, P., Vermeir, I., \& Verniers, S. (2001). An empirical investigation of the relationships between ethical beliefs, ethical ideology, political preference and need for closure. Journal of Business Ethics, 32(4), 347-361.

Visser, W. (2006). Revisiting Carroll's CSR pyramid. Corporate citizenship in developing countries, 29-56.

Visser, W. (2009). Corporate Social Responsibility in Developing Countries. In The Oxford Handbook of Corporate Social Responsibility. https://doi.org/10.1093/oxfordhb/9780199211593.003.0021 
Vitell, S. J., Ramos, E., \& Nishihara, C. M. (2010). The role of ethics and social responsibility in organizational success : A Spanish perspective. Journal of Business Ethics, 91(4), 467-483. https://doi.org/10.1007/s10551-009-0134-9

Vogel, D. (1986). The study of social issues in management: A critical appraisal. California management

review, $28(2)$, $142-151$. https://doi.org/10.2307/41165191

Wong, A. \& Yameogo, U. K. S. (2011). Les responsabilités sociétales des entreprises en Afrique francophone. Editions Charles Léopold Mayer.

Wood, D. J. (1991). Corporate Social Performance Revisited. The Academy of Management Review, 16(4), 691-718. https://doi.org/10.2307/258977 